УДК 9

DOI $10.21661 / \mathrm{r}-467304$

\title{
А.Н. Кохичко
}

\section{О РОДИНЕ, ОТЧИЗНЕ, ОТЕЧЕСТВЕ}

Аннотация: среди базовых начиональных ценностей, выступивших основой духовно-нравственного развития, воспитания $u$ социилизации обучающихся, особое место занимает патриотизм. Несмотря на актуальность формируемой категории, анализ литературы по теме исследования указывает как на противоречивость трактовок патриотизма, так и на его недостаточное методологическое обоснование. $B$ данной статье раскрываются основы и содержание патриотизма в отечественной языковой ментальности.

Ключевые слова: базовые национальные ценности, патриотизм, родина, отчизна, отечество, любовь.

\section{A.N. Kokhichko}

\section{ABOUT THE HOMELAND, MOTHERLAND, FATHERLAND}

Abstract: summary: patriotism occupies a special place among the basic national values, which became the basis of spiritually-moral development, education and socialization of students. Despite the relevance of the generated categories, the analysis of pedagogical literature on the research topic highlights both the contradictory interpretations of patriotism, and for its lack of methodological justification. This article covers the basics and the content of patriotism in the national language mentality.

Keywords: basic national values, patriotism, Motherland, Fatherland, homeland, native land, love.

«Основным содержанием духовно-нравственного развития, воспитания и социализации, - отмечается в «Концепции духовно-нравственного развития и воспитания личности гражданина России» $[2$, с. 6], - являются базовые 
национальные ценности, хранимые в социально-исторических, культурных, семейных традициях многонационального народа России, передаваемые от поколения к поколению и обеспечивающие успешное развитие страны в современных условиях» [2, с. 18].

«Патриотизм, - по мнению авторов документа государственного образца, чувство и сформировавшаяся позиция верности своей стране и солидарности с ее народом. Патриотизм включает чувство гордости за свое Отечество, малую Родину, т.е. город или сельскую местность, где гражданин родился и воспитывался. Патриотизм включает активную гражданскую позицию, готовность к служению Отечеству» [2, с. 7].

Тем не менее, несмотря на актуальность поставленной проблемы [6; 7], смешение, градация, противопоставление рядом авторов гражданского, правового, политического, нравственного, патриотического, военнопатриотического, религиозного, интернационального и других аспектов воспитания, ориентация на наполнение национальных (российских, общероссийских) ценностей «общечеловеческим» содержанием (ср., например, терпеливость - терпимость, соборность - солидарность и т. д.), свидетельствуют о противоречивости и недостаточной методологической разработанности не только содержания патриотического воспитания, но и самого понятия «патриотизм».

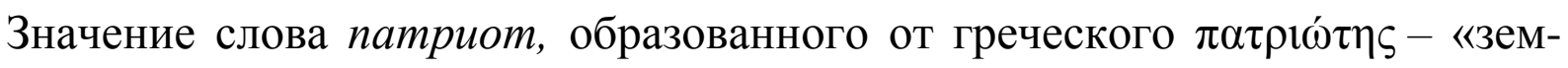
ляк», «соотечественник», «туземец» [11, Т. 2, с. 27; 23, Т. 3, с. 217; 24, с. 292], было изменено в романских языках. В России патриот в значении «сын отечества» через немецкое Patriot (первые упоминания относятся к XVI в.) или французское patriote от среднелатинского patriōta (pater, patris - «отец», «родители», «глава», «распорядитель», patria - «происхождение по отцу» > «поколение»> «род, племя»> «отчизна», «отечество»), начинает употребляться в Петровскую эпоху.

В лексике русского языка под «патриотизмом» понимается:

«Любовь къ отчизнђ» [1, Т. 3, с. 197]. 
«Любовь къ отечеству» $[14$, с. $644 ; 15$, с. $422 ; 17$, Т. 3, с. 163$]$.

«Любовь къ отечеству, ревность о его славь и чести» [11, Т. 2, с. 27].

«Любовь, преданность отечеству и своему народу» [3, с. 496].

«Любовь, преданность и привязанность к отечеству, своему народу» [22, c. 442].

«Преданность и любовь к своему отечеству, к своему народу» [9, с. 496].

«Любовь къ отечеству, къ своей культуръ, желаніе служить своей странъ, защищая ее отъ вторженія внешнихъ враговъ, развивая ея права и вольности, поддерживая ея законы и учрежденія» [8, с. 354].

«Любовь к родине, преданность своему отечеству, своему народу» $[13$, c. $367 ; 16$, T. 3 , с. $22 ; 18$, c. 499$]$.

«Любовь къ родной странъ, желаніе быть полезнымъ отечеству, своему народу» [8, с. 386] и пр.

Как видим, основанием отечественного патриотизма является любовь, в одном случае к родине (родной стране), в других - к отечеству, к отчизне. Несмотря на сближение родины с отечеством и отчизной, рассмотрим данные понятия более подробно.

Древнерусское родина, как отмечают А. Преображенский, О.Н. Трубачев, М. Фасмер, Г.П. Цыганенко, П.Я. Черных и др., образовано от общеславянского $\operatorname{rod}$ ( ord b) - «происхождение» («рождение») > «место рождения» > «отчизна» (отечество»), где индоевропейский корень uerdh-: uredh- (urōdh-) - «расти», «разрастаться», «прибывать», «подниматься». Допустимо думать, что праславянское $\operatorname{ordb}$ родственно арамейскому ordi- «сын», хеттскому hardu- - «правнук». Родина в значении «родная страна» впервые встречается у Г. Державина [11, T. 2 , c. $208-209 ; 23$, T. 3 , c. $491 ; 24$, c. $358 ; 25$, T. 2 , c. $118-119]$.

Родъ в древнерусском языке, в аргументации И.И. Срезневского, употреблялось в значениях: «рожденіе; происхожденіе; семья, родня, родственники; родъ, покольніе; родъ, совокупность покольній, происходящихъ отъ одного родоначальника; племя, народъ; родина; соплеменникъ, землякъ; совокупность людей съ общими отличительными чертами; родъ, порода; родъ, совокупность 
предметовъ съ общими главными качествами; природное свойство; родъ, грамматическій терминъ; урожай; судьба (?); названіе божества древнихъ Славянъ; геенна; гора [21, Т. 3. Ч. 1, с. 135-138]. Таким образом, исходное значение родины - «происхождение» («рождение»), затем - «семья», «родня», «родственники», далее - «место рождения», в итоге - «родная страна», («отчизна», «отечество»).

Древнерусские отьчьство и отьчьствие являются производными от общеславянской основы otbk (отец). Старшее значение - «земля отцов» [25, Т. 1, c. 611]. В общеславянском otbcb (корень ot-, суффикс -bc-) индоевропейский корень at- (> о.-с. ot-), характерный для детской речи. Удвоенная форма atta coхраняется в готском atta (откуда личное имя Attila), также в древневерхненемецком atto, латинском atta, греческом ó $\tau \tau \alpha$ - «папаша», осетинском ćeda - тж., древнеиндийском attāa - «мать», «старшая сестра матери» (как слово детской речи оно известно и в неиндоевропейских языках: турецком ata-«отец», черкесском atte- тж. и др.) $[11$, Т. 2, с. 668; 23, Т. 3, с. 170; 25, Т. 1, с. 611].

Как отмечает И.И. Срезневский [21, Т. 2. Ч. 1, с. 833-834], отьчьство (отечество, отчество) в древнерусском языке означало: «отечество, родина; избранная страна; род; свойства отца; званіе духовника; насльдственыя, родовыя права; отеческая честь, достоинство».

Слово отьчизна, отмечаемое в памятниках с XV века, образованное от отьчий «отцовский, идущий от отцов» > «отцовский, родной, родительский» [24, с. 283], в древнерусском языке значило: «отцы, предки, родъ; вотчина, родовое владъніе; право родового владънія» [21, Т. 2. Ч. 1, с. 830].

Терминологизация понятий отьчьство и отьчизна - явление более позднее, закончившееся уже к XVII в [25, T. 1, с. 611].

Признавая синонимичность родины, отечества и отчизныл, нашедшей отражение в современной лексике русского языка, отметим, что исторически у вышеназванных понятий в отечественной ментальности есть и содержательные оттенки.

Традиционно под родиной понималось: 
«МЊсто, гдђ кто родился. Здъьсь моя родина» [17, Т. 4, с 67].

«Родимая страна, мъсто проживанія въ раннемъ возрасть; < ..> родина - это уъездъ, губернія, гдъ выросъ человекъ» [8, с. 511].

«Родимая земля, мњсто рожденья кого; в обширномъ значеніи земля, государство, гдъ кто родился; в тесномъ городъ, деревня. И кости по родинғ плачуть (по преданію, что въ нъкоторыхъ могилахъ слышенъ вой костей» $[1$, Т. 4, с. 7] и пр.

Отчизна: «Достояніе, насльдство посль отца» [10, с. 399].

Отечество:

«Государство въ коемъ человекъ родился и воспитался» <...> «государство, въ которомъ находится родина» [8, с. 371].

«Государство въ отношеніи к тому, кто въ немъ родился, или сдълался подданым. Любовь къ отечеству. Защищать отечество» [17, Т. 3, с. 496].

«Родная земля, отчизна, гдъ кто родился, выросъ; корень, земля народа, къ коему кто, по рожденью, языку и върђ принадлежитъ; государство, въ отношеніи къ подданымъ своимъ; родина, въ обширном смыслъ. Отецъ мой выходещъ, $а$ мое отечество Русь, руское государство. Второе отечество, земля, гдъ выходецъ поселился, принявъ подданство, или прочно, навсегда водворившись. $3 a$ отечество живот кладутъ, о воинахъ. <...> Рыбам море, птицам воздух, а человеку отчизна вселенный круг. Отчизнушка, отчизненка ты моя!» [1, Т. 2, c. 1299].

Согласно исследованиям В.В. Колесова, Д.В. Колесова, А.А. Харитонова [5, Т. 2, с. 180], «Родина - общность рождения народа, восходящая к предкам (порода) в неизменной среде обитания (природа).

Представляет собой единство места (ро́дина), времени (родина́) и субъектов рождения (роди́на как родичи) применительно к отдельному лицу; единство земли, государства и веры предков, т.е. физической, социальной и духовной слитности представлений о том, что, являясь ключевым понятием культуры, всегда обозначалось как Родина».

Отчизна - родное отечество как место рождения. 
Предполагается, что человек относится к Отчизне как к одному из родителей, поэтому готов служить ей вплоть до своей смерти» [5, Т. 1, с. 586].

«Отечество, - продолжают авторы, - земля отщзов как символ животворности места, жизнеспособности рода (родина) и права народа на наследственное владение (отчизна).

Для Отечества социальные признаки власти владения и власти важны наряду с природно-физическими и духовно-идеологическими (ср. царство-государство): Отечество передается от отцьов к сыновьям и всегда пребывает в оmчине (отчина/вотчина «земля предков», отчий край). < ..> Отечество дает силу и питает, при этом само нуждается в защите от врагов» [5, Т. 1, с. 578-579].

Подводя итог изложенному выше, отметим, что ментально родина - «место рождения», «родная (родимая) страна (земля)» (губерния, уезд, город, деревня и пр.) субъекта (индивидуума, народа). Помимо природно-физического (места и времени рождения) и сощиального (субъектов рождения - родичей) содержания, анализируемое понятие подразумевает и духовнылй (духовно-идеологический, культурологический, культурно-исторический) аспект - язык, веру и пр.

Отечество - «земля отцов (отцовская, идущая, передаваемая от отцов)»«государство, в котором находится родина», «государство, в котором человек родился и воспитался (сделался подданным, навсегда водворился)».

Отчизна - «родное отечество как место рождения», «право субъекта (индивидуума, народа) на наследство после отца, наследственное владение достоянием».

Аргументацию для нашей позиции мы находим и в отечественной философской мысли. «В слове отечество, которым обозначается на всех почти языках союз национально-государственный, - констатирует В.С. Соловьев [20, с. 291], ясно выражается внутренняя, существенная связь между первоначальною общественною клеточкой - родом и широкою политическою организацией. Выражая отношение родственное, термин «отечество» (patria, Faterland и т. д.) указывает этим < ..> на то, что нравственный принцип этого нового великого союза должен быть <..> тот же, как и принцип малого союза - родового». 
Определяя истоки и содержательные признаки отечественного патриотизма, русский мыслитель писал: «Когда собирательная жизнь человечества держалась на кровной связи между членами отдельных небольших групп, чувство общественной солидарности совпадало с чувством семейным. Такой первичный патриотизм рода или племени совместен и с кочевым бытом. При переходе племен к оседлому земледельческому быту патриотизм получает свое специфическое значение, становясь любовью к родной земле. Это чувство естественно слабеет в городском быту, но здесь развивается новый элемент патриотизма - привязанность к своей культурной среде или к родной гражданственности. С этими естественными основаниями патриотизма как природного чувства соединяется его нравственное значение как обязанности и добродетели. Основной долг благодарности к родителям, расширяясь в своем объеме, но, не изменяя своей природы, становится обязанностью по отношению к тем общественным союзам, без которых родители произвели бы только физическое существо, но не могли бы дать ему преимуществ достойного, человечного существования. Ясное сознание своих обязанностей по отношению к отечеству и верное их исполнение образуют добродетель патриотизма, которая издревле имела и религиозное значение, отечество не было только географическим и этнографическим термином - оно было вотчиной особого бога, который сам <..> был <..> отдаленной трансформацией умершего родоначальника. Таким образом, служба родине была деятельным богослужением, и патриотизм совпадал с благочестием. Не культ зависел от родины, а родина < ..> создавалась культом: отечество было землей отцовских богов $<\ldots>$ ». «Если мы все наше физическое и духовное достояние получили от отцов, то отцы имели его только чрез отечество. Семейные предания суть дробь преданий народных, и будущность семьи нераздельна с будущностью народа. Поэтому необходимо почитание отцов переходит в почитание отечества, или патриотизм, и семейное воспитание примыкает к воспитанию национальному» [19, c. 499].

Таким образом, патриотизм, как осознание своих обязанностей по отношению к отечеству и верное их исполнение (добродетели), формируется в 
этнокультурной среде (родной гражданственности), прежде всего в семье, которая, по утверждению В.В. Розанова, - «ближайшее и самое дорогое для нас отечество; пространственно - это место самых горячих связей; духовно - это место совершенного идеализма, живого, лучащегося» [12, с. 196].

Ранее мы отмечали, что фундаментом отечественного патриотизма является любовь к родине, к отечеству, к отчизне. Трудно в связи с этим не согласиться с утверждением И.А. Ильина, по мнению которого: «Есть на свете предметы, которые можно воспринять только глазом (например, свет или цвет); есть такие предметы, которые могут быть восприняты только любовью <..> К таким предметам принадлежит Родина. С человеком, у которого нет реального, живого опыта в этой сфере, который никогда не ощущал сердцем, что есть для него Родина, трудно было бы даже беседовать на эту тему...» [4, с. 218]. «Человек находит Родину, - утверждал мыслитель, - не просто инстинктом, но инстинктивно ускоренным духом и имеет ее любовью. А это значит, что вопрос о Родине разрешается в порядке самопознания и добровольного избрания... <..> заставить человека любить какую-нибудь страну, как свою родину, или быть националистом чуждой ему нации невозможно. Любовь возникает сама, она есть дело свободы человеческого самоопределения. Предмет, именуемый Родиною, настолько сам по себе объективно и безусловно прекрасен, что душа, нашедшая его, обретшая Родину, - не может не любить... Человек не может не любить свою Родину; если он не любит ее, то значит, что он ее не нашел и не имеет» [4, с. 222223].

И не случайно, на наш взгляд, великий русский писатель, этнограф и лингвист В.И. Даль [1, Т. 2, с. 1299, Т. 3, с. 19] предложил вместо чужеродного патриота воспользоваться русскими словами отечественник, отчелюбец, отчизник, отчизнолюб, отчизнолюбец..

Таким образом, отечественный патриотизм как «любовь к (большому) Отечеству» начинается с «любви к (малой) Родине».

А что есть Родина? Что есть Отечество? Что есть Отчизна? Любовь! 


\section{Список литературы}

1. Даль В.И. Толковый словарь живаго великорусскаго языка: В 4 т. [Текст] / В.И. Даль. - М.: Типографія А. Семена; Типографія Лазаревскаго института восточныхъ языковъ (А. Мамонтовъ); Типографія Т. Рисъ, 1863-1866. - Т. 1: А-3. 627 с.; Т. 2: И-О. 1351 с.; Т. 3: П-Р. 508 с.; Т. 4: C-V. 709 c.

2. Данилюк, А.Я., Кондаков, А.М., Тишков, В.А. Концепция духовно-нравственного развития и воспитания личности гражданина России [Текст] / А.Я. Данилюк и др. - М.: Просвещение, 2011. - 23 с.

3. Егорова, Т.В. Словарь иностранных слов современного русского языка [Текст] / Т.В. Егорова. - М.: Аделант, 2014. - 800 с.

4. Ильин И.А. Путь к очевидности [Сборник] [Текст] / И.А. Ильин; послесл. В.И. Кураева; примеч. Р.К. Медведевой. - М.: Республика, 1993. - 430 с.

5. Колесов В.В. Словарь русской ментальности: в 2 т [Текст] / В.В. Колесов Д.В. Колесов, А.А. Харитонов [и др.]. - СПб.: Златоуст, 2014. - Т. 1. А-О. 592 с.; Т. 2. П-Я. $592 \mathrm{c.}$

6. Кохичко А.Н. Об истоках русского патриотизма [Текст] / А.Н. Кохичко // Философия, вера, духовность: истоки, позиция и тенденция развития: монография / Под общ. ред. О.И. Кирикова. - Книга 16. Глава XVIII. - Воронеж: ВГПУ, 2008. - С. 212-224.

7. Кохичко А.Н. Этнокультурный компонент патриотического воспитания младших школьников [Текст] / А.Н. Кохичко // Начальная школа плюс До и После. - 2008. - №10. - С. 3-6.

8. Новый полный словарь иностранныхъ словъ, вошедшихъ въ русскій языкъ [Текст] / Сост. по русск. и иностр. источникамъ Е. Ефремовъ; под ред. проф. И.А. Бодуэнъ-де-Куртенэ. - 2-е изд. - М.: Т-во А.А. Левенсонъ, 1912. $605 \mathrm{c}$.

9. Ожегов С.И. Толковый словарь русского языка: 80000 слов и фразеологических выражений [Текст] / С.И. Ожегов, Н.Ю. Шведова. - 4-е изд. - М.: А ТЕМП, 2004. - 944 c. 
10. Полный церковно-славжнскій словарь (со внесеніемъ въ него важнъйшихъ древне-русскихъ словъ и выраженій) [Текст] / Сост. Г. Дьяченко. - М.: Типографія Вильде, 1900. - 1120 с.

11. Преображенскій А. Этимологическій словарь русскаго языка: В 3 т. [Текст] / А. Преображенскій. - М.: Типографія Г. Лисснера и Д. Совко, 19101914. - Т. 1.674 (5) c.; Т. 2. 419 c.; М. - Л.: АН СССР, 1949. Т. 3.144 c.

12. Розанов В.В. Нечто из седой древности // Религия. Философия. Культура [Текст] / В.В. Розанов; сост. и вступ. ст. А.Н. Николюкина. - М.: Республика, 1992. - C. 193-224.

13. Словарь иностранных слов [Текст] / Зав. ред. В.В. Пчелкина. - 14-е изд., испр. - М.: Рус. яз., 1987. - 608 с.

14. Словарь иностранныхъ словъ, вошедшихъ въ составъ русскаго языка [Текст] / Сост. подъ редакціею А.Н. Чудинова. - СПб.: Изданіе книгопродавца В.И. Губинскаго, 1894. - 989 (3) с.

15. Словарь иностранныхъ словъ, вошедшихъ въ составъ русскаго языка [Текст] / сост. по Энциклопед. Словарю Ф. Павленкова, съ соотв. сокращ. въ объясн. словъ и добавл. въ ихъ числь. - 2-е изд. Ф. Павленкова. - С.-Пб.: Типографія Ю.Н. Эрлихъ, 1907. - 714 (11) с.

16. Словарь русского языка: в 4-х т [Текст] / АН СССР, Ин-т рус. яз. / Под ред. А.П. Евгеньевой. - 2-е изд., испр. и доп. - М.: Русский язык, 1981-1984. - Т. 1. А-Й. 1981. 698 с.; Т. 2. К-О. 1982.736 с.; Т. 3. П-Р. 1983.752 с.; Т. 4. С-Я. 1984. $794 \mathrm{c}$.

17. Словарь церковно-славянскаго и русскаго языка [Текст] / сост. вторымъ отдъленіемъ Императорской Академіи Наукъ. - СПб.: Типографія Императорской Академіи Наукъ, 1847-1868. - T. I. 416 с.; T. II. 475 с.; T. III. 593 с.; T. IV. $491 \mathrm{c}$.

18. Современный толковый словарь русского языка [Текст] / Гл. ред. С.А. Кузнецов. - М.: Ридерз Дайджест, 2004. - 960 с. 
19. Соловьев В.С. Смысл любви / Сочинения в 2 т. Т. 2 [Текст] / Общ. ред. и сост. А.В. Гулыги, А.Ф. Лосева; примеч. С.Л. Кравца и др. - М.: Мысль, 1988. C. $493-547$.

20. Соловьев, В.С. Три речи в память Достоевского / Сочинения в 2 т. Т. 2 [Текст] / Общ. ред. и сост. А.В. Гулыги, А.Ф. Лосева; примеч. С.Л. Кравца и др. М.: Мысль, 1988. - С. 289-323.

21. Срезневскій, И.И. Материілы для словаря древне-русскаго языка по письменнымъ памятникамъ [Текст] / И.И. Срезневскій. - СПб.: Изданіе Отдъленія русскаго языка и словесности Императорской Академіи Наукъ, Императорской Академии Наук, 1893. - Т. І. Ч. І. А-Д. 806 с.; Ч. II. Е-К. 1618 с.; Т. II. Ч. I. Л-О. 852 c.; Ч. II. П. 1802 c.; Т. III Ч. I. P-C. 910 c.; Ч. II. T-GD. 1969 c.

22. Ушаков, Д.Н. Толковый словарь современного русского языка [Текст] / Д.Н. Ушаков. - М.: Аделант, 2014. - 800 с.

23. Фасмер, М. Этимологический словарь русского языка: в 4 т [Текст] / М. Фасмер; пер. с нем. и доп. чл.-кор. АН СССР О.Н. Трубачева. - 2-е изд. стереотип. - М.: Прогресс, 1986-1987. - Т. I (А-Д). 576 с.; Т. II (Е-Муж). 672 с.; Т. III (Муза-Сят). 832 с.; T. IV (Т-ящур). 864 с.

24. Цыганенко Г.П. Этимологический словарь русского языка: более 5000 слов [Текст] / Г.П. Цыганенко. - 2-е изд., перераб. и доп. - К.: Рад. шк., 1989. $576 \mathrm{c}$.

25. Черных П.Я. Историко-этимологический словарь современного русского языка: в 2 т. - 3-е изд., стереотип [Текст] / П.Я. Черных. - М.: Рус. яз., 1999. - Т. 1: А-Пантомима. - 624 с.; Т. 2: Панцирь-Ящур. - 560 с.

\section{References}

1. Dahl, V. I. Explanatory dictionary of living great Russian language in 4 volumes [Text] / V.I. Dal. - M.: Printing house of A. Seeds; Printing Lazarev Institute of Oriental languages (A. Mamontov); Printing T. Rice, 1863-1866, he was. - Vol. 1: AZ. 627 p.; Vol. 2: I-O. 1351 p.; Vol. 3: P-R. 508 p.; Vol. 4: S-V. 709 p. 
2. Danyluk, A.Y., Kondakov, A.M., Tishkov, V.A. The Concept of spiritualmoral development and education of the person citizen of Russia [Text] / A.Y. Danilyuk and others. - M.: Education, 2011. - 23 p.

3. Egorova, T.V. Dictionary of foreign words of the modern Russian language [Text] / T.V. Egorova. - M.: Adelant, 2014. - 800 p.

4. Ilyin, I.A. Way to evidence [Collection] [Text] / I.A. Ilyin; afterword. I.V. Kuraeva; note. R.K. Medvedeva. - M.: Republic, 1993. - 430 p.

5. Kolesov, V.V., Kolesov, D.V., Kharitonov, A.A. Dictionary of the Russian mentality: in 2 volumes [Text] / V.V. Kolesov and others. - S.-Pb.: Zlatoust, 2014. Vol. 1. A-O. p. 592; Vol. 2. P-JA. p. 592.

6. Kokhichko, A.N. About the origins of Russian patriotism [Text] / A.N. Kokhichko // Philosophy, faith, spirituality: the origins, the position and trend of development: monograph / under the General editorship of O.I. Kirikova. - Book 16. Chapter XVIII. - Voronezh: VSPY, 2008. - P. 212-224.

7. Kokhichko, A.N. Ethno-cultural component of Patriotic education of younger schoolchildren [Text] / A.N. Kokhichko // Elementary school plus Before and After. 2008. - №. 10. - P. 3-6.

8. New complete dictionary of foreign words included in the Russian language [Text] / sost. in Russian. foreign. sources E. Efremov; under the editorship of Professor I. A. Baudouin de Courtenay. - Ed. 2. - Moscow: T-vo A.A. Levenson, 1912. - 605 p.

9. Ozhegov, S.I., Shvedova, N.Yu. Explanatory dictionary of Russian language: 80,000 words and phraseological expressions [Text] / S.I. Ozhegov and others. 4th ed. - M.: AND PACE, 2004. - 944 p.

10. Full Church Slavonic dictionary (with the introduction of ancient the most important words and expressions) [Text] / sost. G. Diachenko. - M.: Printing House Of Vilde, 1900. - $1120 \mathrm{p}$.

11. Preobrazhensky, A. Etymological dictionary of the Russian language: in 3 volumes [Text] / A. Preobrazhensky. - M.: Printing house of G. Lissner and D. Sovko, 1910-1914. - Vol. 1. 674 (5) p.; Vol. 2. 419 p.; M.-L.: A of S USSR, 1949. Vol. 3. $144 \mathrm{p}$. 
12. Rozanov, V.V. Something from ancient times // Religion. Philosophy. Culture [Text] / V.V. Rozanov; ed. and joined. article A.N. Nikolyukin. - M.: Respublika, 1992. - P. 193-224.

13. Dictionary of foreign words [Text] / head. the editorship of V.V. Pchelkina. 14-nd ed., rev. - M.: Rus. lang., 1987. - 608 p.

14. Dictionary of foreign words included in the Russian language [Text] / sost. edited by A.N. Chudinov. - S.-Pb.: Publication the bookseller V. Gubinsky, 1894. 989 (3) p.

15. Dictionary of foreign words included in the Russian language [Text] / sost. at Encycloped. Dictionary F. Pavlenkova, respectively. cont. in expl. words and add. in one of them. - 2-nd ed. F. Pavlenkova. - S.-Pb.: Printing House Of Y.N. Ehrlich, 1907. - 714 (11) p.

16. Russian dictionary: in 4 t. [Text] / A of S USSR, In-t Rus. yaz. / under the editorship of A.P. Evgenieva. - 2-nd ed. rev. and extra - M.: Russian language, 19811984. - Vol. 1. A-I. 1981.698 p.; Vol. 2. K-O. 1982.736 p.; Vol. 3. P-R. 1983.752 p.; Vol. 4. S-JA. 1984. 794 p.

17. Dictionary of Church Slavonic and Russian language [Text] / sost. second division of the Imperial Academy of Sciences. - S.-Pb.: Typography Of Imperial Academy Of Sciences, 1847-1868. - Vol. I. 416 p.; Vol. II. 475 p.; Vol. III. 593 p.; Vol. IV. $491 \mathrm{p}$.

18. Modern dictionary of Russian language [Text] / chief editor S. A. Kuznetsov. - M.: Reader's Digest, 2004. - 960 p.

19. Soloviev, V.S. Sense of love / Works in 2 vols 2. [Text] / ed. and comp. A.V. Gulyga, A.F. Losev; note. S.L. Kravets and others. - M.: Thought, 1988. - P. 493-547.

20. Soloviev, V.S. Three speeches in memory of Dostoevsky / Works in 2 vols 2. [Text] / ed. and comp. A.V. Gulyga, A.F. Losev; note. S.L. Kravets and others. - M.: Thought, 1988. - P. 289-323.

21. Sreznevsky, I.I. Materials for the dictionary of old Russian language according to written monuments] [Text] / I.I. Sreznevsky. - S.-Pb.: The publication of Department of Russian language and literature of the Imperial Academy of Sciences, the 
Imperial Academy of Sciences, 1893. Vol I. Part I. A-D. 806 p.; Part II. E- K.1618 p.; Vol. II. Part I. L-O. 852 h.; Part II. P. 1802 p.; Vol. III Part I. R-S. 910 p.; Part II. T-?. 1969 p.

22. Ushakov, D.N. Dictionary of the modern Russian language [Text] / D.N. Ushakov. - M.: Adelant, 2014. -800 p.

23. Fasmer, M. Etymological dictionary of Russian language in 4 volumes [Text] / M. Vasmer; tr. of the deitch. and additional member.-cor. USSR Academy of Sciences O.N. Trubacheva. - 2nd ed. stereotype. - M.: Progress, 1986-1987. Vol. I (AD). 576 p.; Vol. II (E-Husband). 672 p.; Vol. III (Muse-Struck). 832 p.; Vol. IV (TIA). $864 \mathrm{p}$.

24. Tsyganenko, G.P. Etymological dictionary of the Russian language: more than 5,000 words [Text] / G.P. Tsyganenko. - 2nd ed. - K.: Rad. sh., 1989. - 576 p.

25. Chernych, P.J. Historical-etymological dictionary of modern Russian language: in 2 vol 3rd ed. stereotype [Text] / P.J. Chernych. - M.: Rus. lang., 1999. Vol. 1. A-Mime. 624 p.; Vol. 2. Shell-JA. 560 p.

Кохичко Андрей Николаевич - д-р пед. наук, доцент, профессор кафедры педагогики ФГБОУ ВО «Мурманский арктический государственный университет», Россия, Мурманск.

Kokhichko Andrey Nikolaevich - doctor of pedagogical sciences, associate professor, professor of the Department of Pedagogy at Arctic Murmansk State University, Russia, Murmansk. 